University of New Hampshire

University of New Hampshire Scholars' Repository

$10-2009$

\title{
Enhancing AIS to Improve Whale-Ship Collision Avoidance and Maritime Security
}

\author{
Philip A. McGillivary \\ US Coast Guard \\ Kurt Schwehr \\ University of New Hampshire, Durham \\ Kevin Fall \\ Woods Hole Oceanographic Institution
}

Follow this and additional works at: https://scholars.unh.edu/ccom

Part of the Computer Sciences Commons, and the Oceanography and Atmospheric Sciences and Meteorology Commons

\section{Recommended Citation}

McGillivary, Philip A.; Schwehr, Kurt; and Fall, Kevin, "Enhancing AIS to Improve Whale-Ship Collision Avoidance and Maritime Security" (2009). IEEE Oceans. 462.

https://scholars.unh.edu/ccom/462

This Conference Proceeding is brought to you for free and open access by the Center for Coastal and Ocean Mapping at University of New Hampshire Scholars' Repository. It has been accepted for inclusion in Center for Coastal and Ocean Mapping by an authorized administrator of University of New Hampshire Scholars' Repository. For more information, please contact Scholarly.Communication@unh.edu. 


\title{
Enhancing AIS to Improve Whale-Ship Collision Avoidance and Maritime Security
}

\author{
Philip A. McGillivary, US Coast Guard PACAREA \\ Kurt D. Schwehr, UNH Center for Coastal Ocean Mapping / Joint Hydrographic Center \\ Kevin Fall, Woods Hole Oceanographic Institution and Intel Research Berkeley
}

\begin{abstract}
Whale-ship strikes are of growing worldwide concern due to the steady growth of commercial shipping. Improving the current situation involves the creation of a communication capability allowing whale position information to be estimated and exchanged among vessels and other observation assets. An early example of such a system has been implemented for the shipping lane approaches to the harbor of Boston, Massachusetts where ship traffic transits areas of the Stellwagen Bank National Marine Sanctuary frequently used by whales. It uses the Automated Identification Systems (AIS) technology, currently required for larger vessels but becoming more common in all classes of vessels. However, we believe the default mode of AIS operation will be inadequate to meet the long-term needs of whale-ship collision avoidance, and will likewise fall short of meeting other current and future marine safety and security communication needs. This paper explores the emerging safety and security needs for vessel communications, and considers the consequences of a communication framework supporting asynchronous messaging that can be used to enhance the basic AIS capability. The options we analyze can be pursued within the AIS standardization process, or independently developed with attention to compatibility with existing AIS systems. Examples are discussed for minimizing ship interactions with Humpback Whales and endangered North Atlantic Right Whales on the east coast, and North Pacific Right Whales, Bowhead Whales, Humpback Whales, Blue Whales and Beluga Whales in west coast, Alaskan and Hawaiian waters.
\end{abstract}

\section{SCOPE OF THE PROBLEM}

Ship traffic continues to increase worldwide and traffic densities are already high (Figure 1). The predicted rate of increase has slowed due to recent economic slowdowns, but gradually ships which were held temporarily idle will return to service. In the near future an anticipated 3\% annual increase in global shipping is likely to be sustained (Schwehr and McGillivary, 2007). Many port construction projects planned in advance of recent economic slowdowns are already underway, and will necessarily be completed to accommodate the probable increase in ship traffic. One example of a port expansion where marine mammals are relatively abundant is the three-fold capacity expansion of the port of Anchorage, which handles $80 \%$ of shipping for the state of Alaska (Prokop, 2006). Similar problems with increased ship traffic are resulting in increases in whale-ship collisions around the

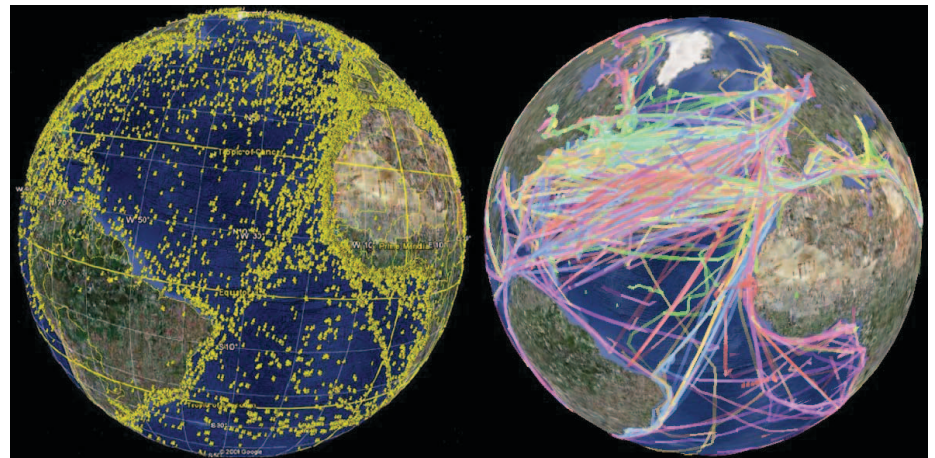

Figure 1: Left globe shows Satellite AIS position reports received for one day by AprizeSat 3 and 4. S-AIS image courtesy SpaceQuest. Right globe shows Voluntary Observation Ship (VOS) tracks for a year. VOS visualization by Ben Smith (University of New Hampshire Center for Coastal Ocean Mapping / Joint Hydrographic Center).

world, from Ecuador to West Africa (Felix and Van Waerebeek, 2005), Australia (Kemper, et al., 2008), in the Mediterranean (e.g. Panigada, et al., 2006), off Spain (De Stepahnis and Urquiola, 2006), and within US waters off Washington State (Douglas, et al., 2008) and Hawaii (Lammers, Pack and Davis, 2007), and in other locations around the US coasts (Jensen and Silber, 2003). To document these occurrences properly an effort is underway to standardize data collection within the US (NOAA, NMML, 2008) and worldwide (Van Waerebeek and Leaper, 2007), but the significance of the problem is not in doubt.

In addition to increased probabilities of ship-whale collisions due to commercial shipping, there is an increase in the use of high-speed ferries worldwide (Weinrich, 2004). Some high speed ferries along the Japanese coast have routes in each direction in excess of sixty miles through areas frequented by whales (Anon., 2007b). Ferry routes around the Canary Islands have resulted in sufficient whale collisions (Aguilar, et al., 2000) to be considered a significant risk to ferry operations (Ritter, 2007). As elsewhere, as whale-ship strikes by the ferries continued to increase, proposals to reduce these collisions with immediate changes to operations were put forward (Carillo and Ritter, 2008). With the risk of ferrywhale collisions well recognized, the failure to properly conduct environmental assessment and avoidance mechanisms for whales in the proposed use of a Superferry in Hawaiian waters was a strong contributor to the abandonment of this project (c.f. Norris, 2008). Federal biologists testified that there was a very high risk of whale-ferry collisions along the ferry routes (Kubota, 2007), contributing to the court ruling that the State had failed to follow required federal Environmental Impact Assessment regulations. The resulting 
delays in operation of the Superferry contributed to the economic failure of the project at considerable cost to the State of Hawaii, which had significantly bankrolled the project.

The problems of ship-whale collisions are likely to become more prominent in the case of endangered and protected whale species, especially those with restricted or highly localized habitat preferences which co-occur with shipping routes. The case of the Cook Inlet beluga whales, which remain resident in the spatially restricted area of fairly heavy ship traffic have led to their federal protection as endangered species (Jans, 2007; Anonymous, 2009; Ezer, Hobbs and Oey, 2009). The migrations of whales through bottleneck areas like the Straits of Gibraltar and Bering Straits likewise increases risks to whales due to increased shipping (Panigada, et al., 2006; Van Waerebeek, et al., 2006). Seasonal north-south migrations of many whale species can exacerbate the problem of ship collisions with these animals in animal when they are concentrated while passing through restricted island passages and straits.

\section{SPECIFIC PROBlem LocAtions AND SPECIES}

The approaches to Boston, MA cross the Stellwagen Bank National Marine Sanctuary (SBNMS) (Figure 2). This area is heavily used feeding ground for endangered marine mammals such as the North Atlantic right whales (Eubalaena glacialis), humpback whales (Megaptera novaeangliae), and fin whales (Balaenoptera physalus). The area is a hot spot for vesselwhale collisions (Jensen and Silber, 2003). The SBNMS compiled a large dataset of whale sightings over 24 years. Based on the gridded density, the US National Oceanographic and Atmospheric Administration (NOAA) worked with the US Coast Guard and International Maritime Organization (IMO) to relocate the Traffic Separation Scheme (TSS) to the north in July, 2007 to put ship traffic in the area least likely to have whales, greatly reducing the chances for whale-ship interaction, similar to a concurrent effort in waters off Southern Spain (Tejedor, et al., 2007). Within the SBNMS ship traffic remains significant: in 2006, 541 large commercial vessels transited the SBNMS 3413 times (Hatch et al., 2008). The large commercial vessels have average maximum speeds (excluding tugs) that range from 15 to 17 knots with one ferry transiting the area at 41 knots. That high-speed vessel traffic combined with the density of whales still in the area transited by vessels still leaves a substantial risk of whale strikes. Because of the failure of protected North Atlantic Right Whales to recover significantly despite their protection since 1935 (Roman, 2000), improving their survival by reducing ship collisions with this species particularly has been a national priority.

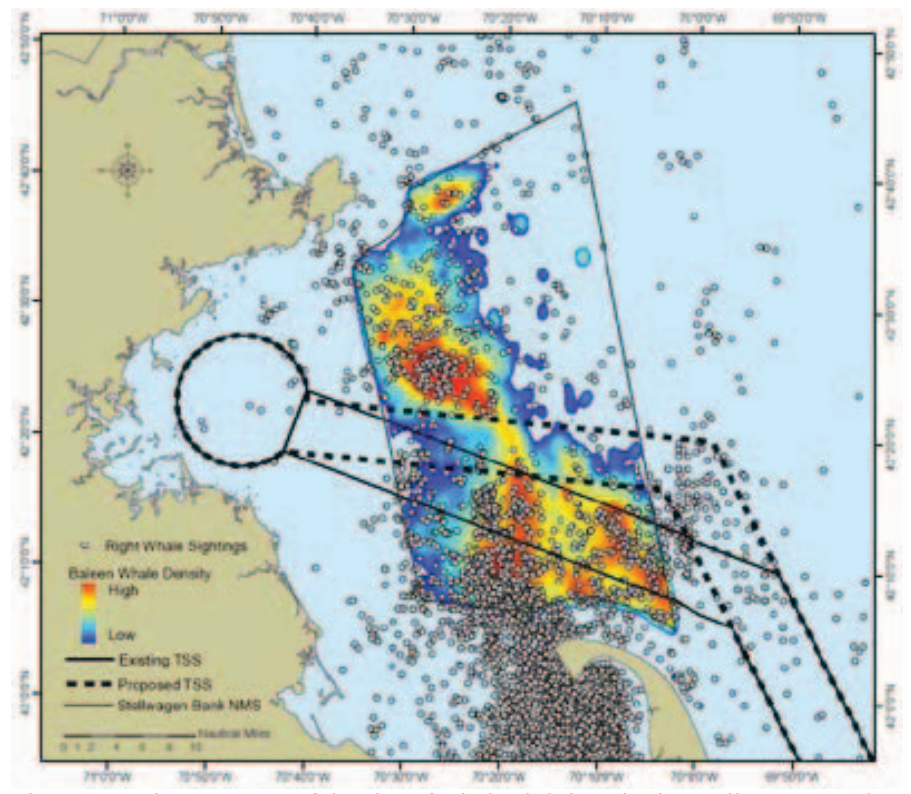

Figure 2: Color contours of density of whale sightings in the Stellwagen Bank National Marine Sanctuary over a 24 year period with overlay of individual right whale sightings. Solid lines show the vessel traffic lanes before July 1 , 2007, while the dotted lines show the traffic scheme after the lanes were moved to the historically low area of the sighting data. Image courtesy of Michael Thomson (Stellwagen Bank National Marine Sanctuary).

In an effort to further reduce the risk of vessel-whale collisions, NOAA, the USCG and two liquefied natural gas companies (LNG) agreed to build a right whale listening network (http://listenforwhales.org) in conjunction with the construction of two deepwater LNG terminals (North East Gateway and Neptune). The system was built by Cornell University and Woods Hole Oceanographic Institution with 10 passive acoustic buoys spaced evenly down the center of the Boston TSS (Page, 2000; Clark and Peters, 2009). Cornell operates and maintains the system providing a website which updates every 20 minutes. Cornell staff monitor the buoys and when the buoys hear right whale calls, they telephone the LNG ships to alert them to monitor their progress to avoid collisions. During periods when there are many right whales in the area, operators must call the ships frequently.

To reduce the load on vessel watchstanders, the University of New Hampshire, Cornell, NOAA, and the USCG are working to provide real time updates over AIS (Figure 3). These messages are automatically decoded by software running on the bridge of the ship and shown as overlays on the displayed charts of the Boston approaches. At present, 1 message for each buoy is sent every 5 minutes, however, without adding separate logging software to the vessels or talking to the bridge crew, it is not currently possible to tell if the ship has received and is displaying whale notices on their bridge electronic charting systems (ECS). One possible future solution to ensuring increased receipt of whale notices by vessels would be to provide an additional AIS channel which could automatically acknowledge receipt of these notifications. 


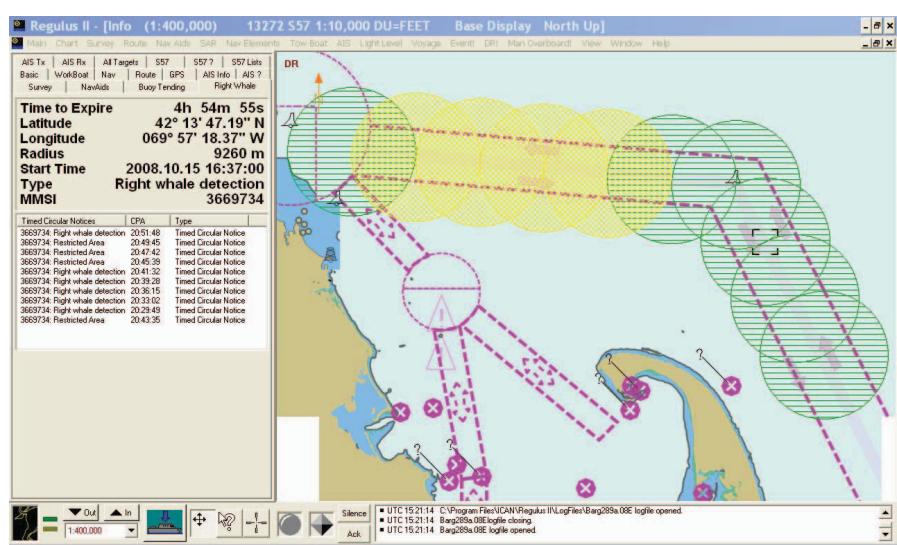

Figure 3: AIS Zone Messages as they are received and shown on ship bridge ECS systems. These messages are broadcast from Province Town, MA on Cape Cod based on acoustic detections of whale calls from buoys. One message for each buoy is sent every 5 minutes. The coverage of the messages is limited to $20-40 \mathrm{~km}$ based on the receiver quality on ships and the daily VHF radio propagation conditions. In this figure each circle represents a buoy and its' detection range; yellow circles represent the presence of whales within the last 24 hours. [Pink X's are feature artifacts from ECS charts.]

The case of the Hawaiian Superferry was already mentioned above. One part of the route for this ship passed directly through particularly favored whale habitat off southeastern Kauai, immediately adjacent to areas protected specifically for whales as part of nursery grounds as part of the Hawaii National Marine Sanctuary. A wide variety of whales favor the area not only during seasonal migration and calving periods, but year round (c.f. Barlow, 2006). During trial runs of the Hawaiian Superferry, damage to the ship's rudders contributed to significant periods of lay-up for repairs for the vessel, incurring considerable financial losses. While it was not definitely determined what caused damage to the rudders, there was speculation that it was a whale collision which accounted for the damage.

The high speed Japanese ferry and the Hawaiian Superferry are similar to many of the newer oil tankers and other cargo ships in moving at much higher speeds than ships in the past. Ship speed has been shown to have a direct effect on whale mortality upon collision (Laist, et al., 2001; Vanderlaan and Taggart, 2007), and can be expected to increase the probability of collision. Restrictions on ship speed have been put in place for areas along the east coast frequented by whales, including around the Stellwagen Bank National Marine Sanctuary to address this issue (Anonymous, 2006; Federal Register, 2008), without causing the economic catastrophe some predicted (Yeomans, 2006). However speed alone is not the only cause of collisions. Cruise ships operating in Alaskan waters, which move slowly through certain scenic passages, also have a history of transiting specific areas frequented by humpback and other whales where collisions are a known risk (Harris and Gende, 2009), and may have contributed to humpback whale deaths (Anon., 2007/2008). And ships slowing to enter the port of San Diego are believed to have accounted for the deaths of two Blue whales within two weeks in October of 2007 (Anon., 2007a). One of the problems currently facing scientists is actually determining whether whales struck by ships were killed by the collisions, or already dead when they were hit.

\section{FloATERS: ShIP StRIKES WITH DEAD WhaleS}

It is sometimes the case that ships that hit whales actually come into port with the whale draped across the bow of the ship, as recently happened in Anchorage, Alaska. A dead whale, or 'floater' is unpleasant to smell, and in this case it was disposed of before scientists had an opportunity to conduct an autopsy to determine cause of death. This case is not unusual, and a lack of autopsies on whales involved in ship collisions complicates understanding of what effects ship collisions actually have on whale populations. Certainly for severely endangered populations like the North Atlantic Right Whale any deaths by ship collisions are a considerable problem, but documenting whale-ship collision deaths is important for all species, and remains problematic to understand how best to avoid whale-ship collisions. Certainly part of the problem in such collisions is not just for whales, it is also for ship operators wishing to avoid damage to their ships by avoiding dead whale collisions. Coast Guard and other records show that dead whales are frequently encountered in the Straits of Juan de Fuca as ships enter the Port of Seattle, and by ferries regularly traversing Puget Sound (c.f. Douglas, et al., 2008). Whale deaths in this area, as elsewhere, often tend to be seasonal events, and are somewhat expected by ships familiar with the area. Because of the restricted area within Puget Sound, official notifications and active removal of carcasses tend to minimize ship collision risks in this area. In many places this is not the case however. Patterns of seasonal whale die-offs are common in many places, and will affect the efficacy of AIS-based whale-ship collision avoidance systems: dead whales don't make calls for acoustic detection systems to hear. Thus while AIS systems such as those deployed on the approach to Boston Harbor can help reduce whale deaths and ship damage, ships transiting areas where dead whales may accumulate still run the risk of a collision. These risks are not simply seasonal, indeed there is considerable inter-annual variation.

During the 1999-2000 season in the Bering and Chukchi Seas there was a pronounced die-off of gray whales (Gulland, et al., 2005). For the entire west coast numbers of dead gray whales alone recorded were 273 in 1999 and 361 in 2000 (Moore, et al., 2001). Many of these were reported in Alaskan waters, where due to the strong currents through the Bering Straits it is probable that many of these whales accumulated in the ship channels and posed a significant risk to shipping. A definitive cause for these deaths has not been established (Le Boeuf, et al., 2000), but it appears that a similar die-off has been underway during 2008 and 2009, affecting both gray and bowhead whales, with a possible cause for some of the deaths being toxins in harmful algal blooms (HABs) (Rosa, 2008 \& 2009). During the 2008 season the number of documented dead bowhead whales was greater that year than in the previous 25 years together (Rosa, 2008). These facts indicate the great inter-annual variability of the occurrence of 'floaters' and suggests a need to address this fact in whale-ship collision avoidance schemes as well. 
Poisoning by domoic acid, a product of HABs is suspected in other whale deaths as well (Anon., 2007a). If this finding is validated, it may allow for monitoring of water in the Bering Straits from seawater intakes on Little Diomede Island to predict when HABs are present and such die-offs might occur, and allow ships to be on guard when transiting the Straits at such times. This sort of monitoring to alert ships to dead whales could complement AIS-based notifications of live whales to reduce whale-ship collisions and minimize ship damage and costs.

Another approach to detection and avoidance of whales can potentially be used to minimize ship collisions with both dead and live whales is called masking detection. This method is being used in the Canary Islands Whale Anti-Collision Systems (WACS), and involves hydrophones used for ambient noise imaging, in which the presence of a whale (dead or alive) produces a sound shadow (Anonymous, 2003). Using multiple buoys spaced $10 \mathrm{~km}$ apart along the $120 \mathrm{~km}$ ferry route in this area movement of whales can be detected by this means as well. This method holds promise for use elsewhere as well, and is being further studied and developed. While active high frequency phased-array sonars may also provide this type of detection capability (Zimmerman and Potter, 2001).

\section{SHIP STRIKES AND ANIMAL BEHAVIOR}

Whales often migrate to specific feeding preference areas, such as submarine canyons on the east coast (c.f. Weinrich, et al., 2000), along the Kona coast of Hawaii (McSweeney, Baird and Mahaffy, 2007), and in the Chirikov Basin area in the Bering Straits just north of St. Lawrence Island (Perryman, et al., 2002). Whale aggregations at specific areas like these increase risks of collision for ships transiting these areas. Whales can also exhibit other behavior which affects their probability of collision with ships, including social aggregations for purposes other than feeding which can result in greatly increased localized densities of two to ten or more whales (Wursig, et al., 1993; Parks, et al., 2007; Anon., 2009). During such social aggregations, whales may be engaging in behavior which may also distract them from responding to the presence or noise of approaching ships. If conditions of partial darkness or fog render these aggregations not readily observed, the risk of collisions with transiting ships is very significantly increased. Some whales are apparently also very sound sleepers: like other species sperm whales often sleep at the surface, where they may sleep so deeply they are not awakened until directly contacted by vessels (Miller, et al., 2008). The fact they often sleep at the surface at night when they are less visible further increases their risk of ship collisions. These facts limit along with sea state and weather pose practical limitations on the effectiveness of dedicated marine mammal observers on ferries as a means of avoiding collisions with whales (Weinrich and Rekarcik, 2007).

In locations where there are seamounts or near island gaps, aggregations of whales may occur in response to localized internal wave induced upwelling of prey items (Moore and Lien, 2007) or tidally generated eddies. Locations just north of Unimak Pass in the Aleutians are known to be favorable feeding habitat for some whale species, particularly humpback whales presumably due to localized upwellings (Friday, et al., 2009). In northern seas, whale species have preferences for specific ice conditions, and may aggregate at the seasonal ice edge or within ice of a certain percent coverage or thickness, such as the heavy ice cover favored by bowhead whales (Burns, et al., 1980; Perryman, et al., 2002; Stafford, et al., 2009). As whales migrate, they may also tend to aggregate in specific areas, including feeding areas such as the critical habitat defined for Gray and Right Whales in the Bering Sea, which may also change with season (Moore, DeMaster and Dayton, 2000; Clark and Moore, 2002; Moore, Grebmeier and Davies, 2003; Zerbini, et al. 2009), or in polynyas, usually coastal areas of open water in otherwise ice-covered seas (Stringer and Grove, 1991), where they may wait for the seasonal retreat of annual ice before proceeding north on their seasonal migrations. There are diel variations in the rates of migration which will affect ship collision rates as well (Perryman, et al., 1999).

For some species local habitat is defined by water depth and/or relation to the shelf break. There is a well-documented differentiation of habitat preference between belugas and bowhead whales along the North Slope of Alaska in the Beaufort Sea. Studies of satellite tagged whales show that Bowheads generally prefer areas closer to the shore, while belugas generally migrate closer to the shelf break (Alaska Department of Fish and Game, 2009; Goetz, Rugh and Mocklin, 2009). However these habitat locations are related to food preferences and also vary with upwelling and wind conditions: when upwelled food is pushed into nearshore waters, bowhead whales will follow them (Goetz, et al., 2009; Ashjian, et al., 2009). As this information becomes more readily available to ships, they can transit along such coastal areas in ways designed to minimize encounters with feeding whales.

Another very significant aspect of whale behavior which influences ship-strike issues relates to their uses and responses to sound. There are aspects of both these issues which are problematic in terms of addressing whale ship-strike issues. Whale sound production is seasonal (c.f. Watkins, et al., 2000; Moore, et al., 2006), and such variations can affect detection rates by passive hydrophone arrays. Using new advances in hydrophone signal analysis, 3D positioning of whales over significant ranges can be used to make such assessments (Laurinolli, et al., 2003; Wiggins, 2003; Wiggins, et al., 2004; Moore, et al., 2006).

Responses of whales to ship noise vary considerably not only with whale behavioral activity (sleeping, feeding, migrating), but also by species. There have been significant studies of oil and gas detection seismic surveys on whale behavior (c.f. Richardson, Miller and Greene, 1999; Gordon, et al., 2003/2004 for a review; Aerts, et al., 2009). Sperm whales in the Gulf of Mexico were reported not to have changed behavior in response to such seismic activity (Anonymous, 2008b; Minerals Management Service, 2008). Other studies have focused on the responses of whales to ship 
noise, both for low latitudes, and in ice-covered seas from icebreaking vessels (Erbe and Farmer, 2000; Hatch, et al., 2008). Studies of sound propagation in arctic regions pose additional challenges for understanding whale response to ship noise due to the occurrence of the sound channel (depth of maximal sound transmission) being effectively at the surface layer and the problem of accurately modeling sound dispersion in such waters (Minerals Management Service, 2009). Such studies are important in determining when communications between whales are masked by such noise as well (Ford,1987).

Methods which began merely by making visual observations of whale responses have advanced to use of passive and active hydrophone tracking, so-called playback studies to determine response to sounds (Tyack, Gordon and Thompson, $2003 / 2004$ ), and most recently involved deployment of tags on whales which measure sound levels generated by and actually experienced by animals (Johnson and Tyack, 2003; Lundquist, 2008). These methods can be used to determine whether ships carrying sonic 'alarms' are effective in alerting whales to their danger in such a way as to minimize ship collisions (McKenna, 2009). There has been considerable discussion about how whales actually detect and respond to ship noise. Some researchers have concluded that whale response varies with the level of ship noise, louder sounds being dispersed in a way which does not permit whales to localize the source of the sound from a ship and thereby avoid it (Gerstein, 2002). The ability to localize and avoid ships due to noise they produce appears to vary with ship size and level of radiated sound: small ships may induce stress and disrupt foraging by animals but permit them to avoid being struck by ships (Jahoda, et al., 2003; Johson, et al., 2006). The understanding of whale response to ship noise is complicated by climate change effects which are resulting not only in species potentially declining in numbers due to reduced food resources (Greene, et al., 2003), but also moving into more northerly waters, where they may be at risk passing through areas like the Bering Straits (Anonymous, 2008a). Climate change is also causing ocean acidification which changes characteristics of sound propagation at frequencies below $1 \mathrm{kHz}$ used by many whale species (Hester, et al., 2008). These changes may complicate whale behavior and acoustic detection in the future.

\section{EXISTING INFRASTRUCTURE - AIS}

The Automatic Identification System (AIS) is a ship-to-ship and ship-to-shore system designed primary for safety of navigation. AIS operates on two 9600 bps marine band channels around $160 \mathrm{MHz}$ using 1 to 12.5 Watts transmit power (Anon. 2007c). While more extensive ranges for AIS messages are contemplated for the future implementations of AIS technology (reviewed in Schwehr and McGillivary, 2007), the current AIS system permits ship-to-ship or ship-to-shore communications over a typical range of $25-40 \mathrm{~km}$. AIS data communications share network bandwidth within a region, referred to as a cell, through use of self-organized time division multiple access (SOTDMA) methods. AIS divides each minute into 2250 slots that are 168 bits of data for the first slot of a message and 256 bits for each slot thereafter. Messages are typically either 1 or 2 slots giving peak theoretical throughputs that range from 6300 to $7950 \mathrm{bps}$ per channel. High loads on the VHF data link (VDL) can cause some vessels to be unable to access slots to transmit AIS messages, leading to failure of the AIS system to fulfill its primary function of increasing safety of navigation. While future implementations of AIS include Satellite AIS (S-AIS) which has shown great promise in providing wide area reception (Lorenzini and Kanawati, 2009), the local cell SOTDMA design of the current AIS prevents satellites from transmitting on these channels.

AIS has been in use since 2001 with mandatory carriage requirements for Safety of Life At Sea (SOLAS) as of July 1, 2002. These carriage requirements, and the fact that AIS transceivers are typically attached to shipboard electronic charting systems (ECS), make AIS an attractive mode of communicating additional information for mariners and shore side authorities. Moller et al. (2005) showed the potential of AIS for evaluating vessel response to notices of whale sightings. It is possible to use a small portion of the available bandwidth for these types of applications, but the proposed NAV-55 update (Anon. 2009c) to IMO Circ. 236 (Anon. 2004) increases the number of extra broadcast message types from 7 to 12 with many subtypes for several of these messages. In high traffic areas, AIS VHF capacity can quickly become saturated if ship or shore authorities were to attempt using all possible message functionality.

Because the initial design focus of AIS was primarily safety of navigation, the current version of AIS has a number of critical shortfalls in addition to restrictions on available bandwidth and range. As presently implemented, AIS has limited retransmit capabilities for a few message types and no retransmit option for the majority. There is often no way to detect dropped packets (typically observed by embedding sequence numbers in packets), and noise is sometimes decoded as valid packets. Further, there is not currently a mechanism to verify that the sender is who they say they are or to encrypt sensitive message information (e.g. about cargo that may be hazardous). All of these factors combine to create a system where a large portion of the AIS message traffic may be problematic. In a recent study highlighting the seriousness of this problem, Calder and Schwehr (2009) reported that 52\% of the messages in a sample dataset had to be rejected as dubious for detailed analysis to assess ship behavior or message accuracy.

\section{POSSIBLE SOLUTIONS}

There are ongoing discussions of increasing AIS bandwidth to allow additional information to be exchanged in routine Advanced Notice of Arrival (ANOA) messages. Such messages can be used to carry a wide range of information such as whale position estimates, but also for other securityrelated purposes (e.g. cargo and passenger manifests). While increasing bandwidth may improve the current situation modestly, bandwidth limitations are not the only capabilities missing from the AIS framework. Additional capabilities, 
such as security (e.g., authentication of messages and privacy of ship position reports), and tolerance to disruption of service, are also required to permit the proposed communications method to comprise a trusted element in support of overall maritime domain awareness (MDA). Furthermore, the ability to extend the capabilities of the existing AIS system to be compatible with bandwidth supplied by other systems (e.g., commercial WiFi or WiMax) is highly desirable.

One communications technology option, called Delay or Disruption Tolerant Networking (DTN), being developed with support from the US Defense Advanced Research Projects Agency, includes a set of protocols providing many of these features (Fall, 2005; McGillivary, Fall and Maffei, 2007). DTN is a research effort with a protocol specified by the DTN Research Group (DTNRG). An open source implementation of the Bundle Protocol for DTN is described at the DTNRG website, http://www.dtnrg.org. DTN can be used to carry authenticated, secure asynchronous messages across a wide variety of underlying communication technologies, including the Internet, where ship Advance Notice Of Arrival (ANOA) messages may be submitted today. The spatial range of existing VHF radio or AIS messaging, now limited by centralized "one-hop" protocols, can also be extended using the DTN ability to use of "multi-hop" communication nodes. DTN uses temporary message storage within communication nodes such that messages delivered using multiple hops are not lost during network outages or times of high network congestion. The multi-hop capability of DTN thus not only improves reliability, it also allows messages to be physically transmitted from vessels beyond the range of current communication methods.

\section{CONCLUSIONS}

The adoption of a new message-based network architecture such as DTN on an additional AIS channel is a useful approach to meeting future AIS maritime communication needs while ensuring compatibility with other commercial technologies. This approach to improving communications can help minimize whale-ship strikes by making data such as whale position information more widely available at lower cost, while providing improved communication capabilities for other AIS data transmission applications also relevant to maritime security. The ramifications of improved communications capabilities could be significant, as improved data sharing can not only provide additional bandwidth for additional ANOA data, but also improve message security (e.g. via authentication), and by reducing incidence of whale-ship collisions improve marine safety, reduce costs of maritime rescue and investigation efforts, avoid expensive ship repairs and schedule delays, and minimize costly closures of commercial fisheries for protection of endangered whale species. In addition to these cost savings for general maritime operations, the methods proposed would specifically provide improved protection for whales, including several critically endangered species.

\section{REFERENCES}

[1] G. Eason, B. Noble, and I.N. Sneddon, "On certain integrals of Lipschitz-Hankel type involving products of Bessel functions," Phil. Trans. Roy. Soc. London, vol. A247, pp. 529-551, April 1955.

Aerts, L.A.M., S.B. Blackwell, C.R. Greene, W.J. Richardson and B.J. Streever. 2009. Sounds from an offshore oil production island and Bowhead whale call characteristics. Alaska Marine Science Symposium, Jan. 19-23, Anchorage, Ak. Online: http://doc.nprb.org/web/symposium/2009/2009 abstract book ALL.pdf

Aguilar, N., M. Carillo, I. Delgado, F. Diaz and A. Brito. 2000. Fast ferries imact on cetaceans in the Canary Islands: collisions and displacement. Procs. $14^{\text {th }}$ Ann. Conf. ECS, Cork, Ireland, 164.

Alaska Department of Fish \& Game. 2009. Summary maps of fall movements of bowhead whales in the Chukchi Sea. Online Report, Feb. 8, 2009, http://www.wc.adfg.state.ak.us/management/mm/bow_move_chukchi_s ea.pdf

Anonymous. 2003. Whale collision avoidance. Ocean News \& Technology, May/June:28

Anonymous, 2004. Guidance on the Application of AIS Binary Messages, IMO, SN/Circ.236, 28 May.

Anonymous. 2006. NOAA recommends new East Coast ship traffic routes. Sea Technology, December:59.

Anonymous. 2007a. Ocean Science [Blue Whale deaths off Southern California] Ocean News \& Technology, 13(8):18.

Anonymous. 2007b. Wave-piercing ferry for Japan. Ocean News \& Technology, 13(8):29.

Anonymous, 2007c. Technical characteristics for an automatic identification system using time division multiple access in the VHF maritime mobile band, Recommendation ITU-R M.1371-3.

Anonymous. 2007/2008. Ship likely killed Humpback whale. Alaska Magazine December2007/January2008:11.

Anonymous. 2008a. Sign of the Whale. Defenders Magazine, Spring:7.

Anonymous. 2008b. Report determines US Gulf whales not harmed by seismic exploration. Ocean News \& Technology, 14(7, Oct./Nov.):23.

Anonymous. 2009a. Beluga whales granted federal protection. Defenders Magazine, Winter:25.

Anonymous. 2009b. High numbers of Right Whales seen in Gulf of Maine. Sea Technology, Feb.:84.

Anonymous, 2009c. Revision of the Guidance on the Application of AIS Binary Messages, Report from the AIS Binary Messages Correspondence Group, Submitted by Sweden, Annex 1, Guidance on the use of AIS Application Specific Messages, IMO NAV 55 conference, London, England, July.

Ashjian, C., R.G. Campbell, J.C. George, S.E. Moore, S.R. Okkonen, B.F. Sherr and E.B. Sherr. 2009. Impact of inter-annual variability in ocean conditions on bowhead feeding near Barrow, Alaska. Poster. Alaska Marine Science Symposium, Jan. 19-23, Anchorage, Ak. Online: http://doc.nprb.org/web/symposium/2009/2009_abstract book ALL.pdf

Barlow, Jay. 2006. Cetacean abundance in Hawaiian waters estimated from a summer/fall Survey in 2002. Marine Mammal Science 22(2):446-464

Burns, J.J., L.H. Shapiro and F. Fay. 1980. The relationships of marine mammal densities and activities to sea ice conditions. In: Environmental Assessment of the Alaska Continental Shelf, Final Reports, Biological Studies 11:489-670.

Calder, B. and K. Schwehr. 2009. Traffic analysis for the calibration of risk assessment methods. US Hydro 2009, May 11-14, Norfolk, VA.

Carillo, M. and F. Ritter. 2008. Increasing numbers of ship strikes in the Canary Islands: proposal for immediate action to reduce risk of vesselwhale collisions. Int. Whal. Commn. Scientific Committee SC/60/BC6.

Clark, C.W. and D.B. Peters. 2009. Acoustic system monitors and mitigates harm to marine mammals in real time. Sea Technology, August:10-14.

Clark, J.T. and S.E. Moore. 2002. A note on observations of gray whales in the southern Chukchi and northern Bering Seas, August-November, 1980-1989. J. Cetac. Res. Manage. 4(3):283-288.

DeStefanis, R. and E. Urquiola. 2006. Collisions between ships and cetaceans in Spain. Int. Whaling Commission Sci. Committee SC/58/BC5.

Douglas, A.B., J. Calambokidis, S. Raverty, S.J. Jeffreys, Da.M. Lambourn, and S.A. Norman. 2008. Incidents of ship strikes of large whales in Washington State. J. Mar. Biol.Assn. UK, doi:10.1017/SOO25315408000295, March 17.

Erbe, C. and D.W. Farmer. 2000. Zones of impact around icebreakers affecting beluga whales in the Beaufort Sea. J. Acoust. Soc. Am. 108(3),Pt.1:1332-1430. 
Ezer, T., R. Hobbs and L-Y. Oey. 2008. On the movement of Beluga whales in Cook Inlet, Alaska. Oceanography 21(4):186-195.

Fall, K. 2005. Disruption Tolerant Networking for heterogenous ad-hoc wireless networks. Procs. Military Communications Conference (MILCON 2005), Oct.17-20, 2005, Atlantic City, NJ.

Federal Register/Vol. 73, No. 198/Friday, October 10, 2008/Rules and Regulations DEPARTMENT OF COMMERCE 50 CFR Part 224 [Docket No. 040506143-7024-03] Endangered Fish and Wildlife; Final Rule To Implement Speed Restrictions to Reduce the Threat of Ship Collisions

AGENCY: National Marine Fisheries Service (NMFS), National Oceanic and Atmospheric Administration (NOAA), Commerce. Online at: http://edocket.access.gpo.gov/2008/pdf/E8-24006.pdf

Felix, F. and K. Van Waerebeek. 2005. Whale mortality from ship strikes in Ecuador and West Africa. LAJAM 4(1):55-60.

Ford, J. 1987. Sound under the ice. Waters, Journal of the Vancouver Aquarium, 10:20-24

Friday, N., A.N. Zerbini, J. Waite, A. Kennedy, B. Rone, P. Clapham and S.E. Moore. 2009. Cetacean distributions in the Bering Sea in the spring and summer 2008. Poster. Alaska Marine Science Symposium, Jan. 19-23, Anchorage, Ak. Online: http://doc.nprb.org/web/symposium/2009/2009 abstract book ALL.pdf

Gerstien, E. 2002. Manatees, bioacoustics and boats. American Scientist 90(2):154-161.

http://www.americanscientist.org/issues/num2/manatees-bioacousticsand-boats $/ 7$

Goetz, K.T., D. Rugh and J.A. Mocklin. 2009. Bowhead Whale Feeding Ecology Study (BOWFEST) aerial surveys: a comparison of Bowhead whale distribution and survey effort in 2007 and 2008 in the vicinity, Barrow, Alaska. Poster. Alaska Marine Science Symposium, Jan. 19-23, Anchorage, Ak. Online:

http://doc.nprb.org/web/symposium/2009/2009 abstract book\%20ALL. $\mathrm{pdf}$

Gordon, J., D. Gillespie, J. Potter, A. Frantzis, M.P. Simmonds, R. Swift and D. Thompson. 2003/2004. A review of the effects of seismic surveys on marine mammals. Mar. Technol. Soc. J. 37(4):16-34

Gulland, F.M.D., M.H. Perez-Cortes, J. Urban, L. Rojas-Bracho, G. Ylitalo, C. Kreuder and T. Rowles. 2005. Eastern gray whale (Eschrichtius robustus) unusual mortality event, 1999-2000: A compilation. NOAA Tech. Memorandum, NWHFS-AFSC-150, Seattle, Wa.

Harris, K. and S.M. Gende. 2009. Observations of the frequency and severity of encounters between humpback whales and cruise ships in northern Southeast, Alaska. Poster. Alaska Marine Science Symposium, Jan. 1923, Anchorage, Ak. Online: http://doc.nprb.org/web/symposium/2009/2009 abstract book ALL.pdf

Hatch, L., C. Clark, R. Merrick, S. Van Parijs, D. Ponirakis, K. Schwehr, M. Thompson and D. Wiley. 2008. Characterizing the relative contributions of large vessels to total ocean noise fields: a case study using the Gerry E. Studds Stellwagen Bank National Marine Sanctuary. Environmental Management, 42(5):735-52, online at doi:10.1007/s00267-008-9169-4.

Hester, K.C., E.T. Peltzer, W.J. Kirkwood and P.G. Brewer. 2008. Unanticipated consequences of ocean acidification: a noisier ocean. Geophys. Res. Letters 35:L19601,doi:10.1029/2008GL034913.

Jahoda, Maddalena, C.L. Lafortuna, N. Biassoni, C. Almirante, A. Azzellino, S. Panigada, M. Zandarelli, and G.N. Di Sciara. 2003. Mediterranean Fin Whale's (Balaenoptera physalus) response to small vessels and biopsy sampling assessed through passive tracking and timing of respiration. Marine Mammal Science 19(1):96-110.

Jans, N. 2007. Alaska's vanishing whales. Defenders Magazine, Spring:20-23.

Jensen, A.S. and G.K. Silber. 2003. Large whale ship strike database. U.S. Department of Commerce, NOAA Technical Memorandum. NMFSOPR. 37pp.

Johnson, M. and P.L. Tyack. 2003. A digital acoustic recording tag for measuring the response of wild marine mammals to sound. IEEE J. Oceanic Engineering 28:3-12.

Johnson, M., P.T. Madsen, P.L. Tyack, A. Bocconcelli and J.F. Borsani. 2006. Does intense ship noise disrupt foraging in deep-diving Cuvier's Beaked Whales (Ziphius cavirostris)? Marine Mammal Science 22(3):690-699.

Kemper, C., D. Coughran, R. Warneke, R. Pirzl, M. Waston, R. Gales and S. Gibbs. 2008. Southern right whale (Eubalaena australis) mortalities and human interactions in Australia, 1950-2006. J. Cetacean Research \& Management 10:1-8

Kubota, G.T. 2007. Biologist says risk of Superferry colliding with whale 'very high'. Honolulu Star-Bulletin Tuesday, Sept. 11, p.A5.
Laist, David W., A.R. Knowlton, J.G. Mead, A.S. Collet and M. Podesta. 2001. Collisions between ships and whales. Marine Mammal Science 17(1):35-75.

Lammers, M.O., A.A. Pack and L. Davis. 2007. Trends in whale/vessel collisions in Hawaiian waters. Int. Whal. Comm. Scientific Committee $\mathrm{SC} / 59 / \mathrm{BC} 14$.

Laurinolli, Marjo H., A.E. Hay, F. Desharnais, and C.T. Taggart. 2003. Localizations of North Atlantic Right Whale sounds in the Bay of Fundy using a sonobuoy array. Marine Mammal Science 19(4):708-723.

Le Boeuf, B.J., M.H. Perez-Cortes, R.J. Urban, B.R. Mate and U.F. Ollevides 2000. High gray whale mortality and low recruitment in 1999: potential causes and implications. J. Cetacean Research \& Management 2:85-99.

Lorenzini, D., Kanawait, M., 2009. SpaceQuest TEXAS III Presentation, Technical eXchange on AIS via Satellite, Washington D.C., Aug 19.

Lundquist, E. 2008. Fish, whales carry sensors for oceanographic research. Marine Technol. Reporter, June:18,19.

McGillivary, P.A., K. Fall and A. Maffei. 2007. Wireless communications advances for maritime use. Applications of new protocols for Delay and Disruption-Tolerant Networking. Sea Technology May:10-14.

McKenna, P. 2009. Conservation: Whale avoidance. New Scientist May 23:3 and online video at:

http://www.newscientist.com/article/dn17163-sonic-alarm-savesmarine-mammals-from-ship-strike.html

McSweeney, D.J., R.W. Baird and S.D. Mahaffy. 2007. Site fidelity, associations, and movements of Cuvier's (Ziphius cavirostris) and Blaineville's (Mesoplodon densirostris) Beaked Whales off the island of Hawai'i. Mar. Mammal Sci. 23:666-687.

Miller, P.J.O., K. Aoki, L.E. Rendell and M. Armano. 2008. Stereotypical resting behaviour of the Sperm Whale. Current Biology 18(1).

Minerals Management Service. 2008. Sperm Whale Seismic Study in the Gulf of Mexico, Synthesis Report. Outer Continental Shelf Study MMS 2008-006. Online at MMS Environmental Studies Program Information System (ESPIS): www.gomr.mms.gov/PI/PDFImages/ESPIS/4/4445.pdf

Minerals Management Service. 2009. Noise Propagation modeling and field testing for the Beaufort and Chukchi Seas. In: Alaska Annual Studies Plan Final FY 2009. Alaska Outer Continental Shelf Region. Anchorage, Alaska, Sept. 2008, pp.187-188.

Moller, J. C., Wiley, D. N., Cole, T. V. N., Niemeyer, M., and Rosner, A. 2005. The behavior of commercial ships relative to right whale advisory zones in the Great South Channel during May of 2005. The 16th Biennial Conference on the Biology of Marine Mammals, Society for Marine Mammalogy; San Diego, CA; December 12-16.

Moore, S.E., D.P. DeMaster and P.K. Dayton. 2000. Cetacean habitat selection in the Alaskan Arctic during summer and autumn. Arctic 53(4):432-447.

Moore, S.E., J. Urban, W.L. Perryman, F. Gulland, H. Perez-Cortes, P.R. Wade, L. Rojas-Brancho and T. Rowles. 2001. Are Gray Whales hitting K hard? Mar. Mammal Sci. 17(4):954-958.

Moore, S.E., J.M. Grebmeier and J.R. Davies. 2003. Gray whale distribution relative to forage habitat in the northeastern Bering Sea: current conditions and retrospective summary. Canadian J. Zool. 81:734-742.

Moore, S.E., K.M. Stafford, D.K. Mellinger and J.A. Hildebrand. 2006. Listening for large whales in the offshore waters of Alaska. Bioscience 56(1):49-55.

Moore, Sue E. and R-C. Lien. 2007. Pilot whales follow internal solitary waves in the South China Sea. Marine Mammal Science 23(1):193-196.

NOAA National Marine Mammal Lab (NMML) Cetacean Assessment \& Ecology Program, Quarterly Report, Jan.-March, 2008. Online: http://www.afsc.noaa.gov/Quarterly/jfm2008/divrptsNMML1.htm

Norris, A. J. 2008. The Hawaii Superferry - Consternation, Agitation and Litigation. The Bulletin (of the US Coast Guard Academy Alumni Association) 70(4):69-72.

Page, D. 2000. Saving the right whales. Science Spectra 21:13,15.

Panigada, S., G. Pesante, M. Zanardelli, F. Capoulade, A. Gannier and M.T. Weinrich. 2006. Mediterranean fin whales at risk from fatal ship strikes. Mar. Pollution Bull. 52:1287-1298.

Parks, S.E., M.W. Brown, L.A. Conger, P.K. Hamilton, A.R. Knowlton, S.D. Kraus, C.K. Slay and P. Tyack. 2007. Occurrence, composition and potential functions of North Atlantic Right Whale (Eubalaena glacialis) surface active groups. Mar. Mammal Sci. 23(4):868-887.

Perryman, W.L., M.A. Donohue, J.L. Laake and T.E. Martin. 1999. Diel variations in migration rates of esastern Pacific gray whales measured with thermal imaging sensors. Mar. Mammal Sci. 15:426-445. 
Perryman, W.L, M.A. Donahue, P.C. Perkins and S.B. Reilly. 2002. Gray Whale calf production 1994-2000: are observed fluctuations related to changes in sesasonal ice cover? Mar. Mammal Sci. 18(1):121-144.

Prokop, D. 2006. The economic impact and logistics of the Port of Anchorage. Canadian Transportation Research Forum, Quebec City, May 28-31, 2006. http://www.ctrf.ca/past conferences.htm

Richardson, W.J., G.W. Miller and C.R. Greene, Jr. 1999. Displacement of migrating bowhead whales by sounds from seismic surveys in shallow waters of the Beaufort Sea. J. Acoust. Soc. Am. 106(4,Pt.2):2281.

Ritter, F. 2007. A quantification of ferry traffic in the Canary Islands (Spain) and its significance for collisions with cetaceans. Int. Whal. Comm. Scientific Committee SC/59/BC7.

Roman, J. 2000. Going down. Wildlife Conservation, June:26-35.

Rosa, C. 2008. A summary of dead, stranded bowhead whales reported in the Chukchi and Beaufort Seas over the last twenty-five years. International Whaling Commission, SC/61/E12.

Rosa, C. 2009. Update on 2008 collection activities related to 'stinky' gray whales in Chukotka, Russia. International Whaling Commission, SC/61/BRG12.

Schwehr, K. and P. McGillivary. 2007. Marine Ship Automatic Identification System (AIS) for enhanced coastal security capabilities: an oil spill tracking application. Procs. Mar. Technol. Soc. Conf., Oct., Vancouver, B.C.

Stafford, K., D.K. Mellinger, P.J. Stabeno, S.L. Nieukirk, S.L. Heimlich and S.E. Moore. 2009. Analysis of acoustic and oceanographic data from the Bering Sea June 2006-May 2007. Poster. Alaska Marine Science Symposium, Jan. 19-23, Anchorage, Ak. Online: http://doc.nprb.org/web/symposium/2009/2009 abstract book ALL.pdf

Stringer, W.J. and J.E. Grove. 1991. Location and areal extent of polynyas in the Bering and Chukchi Seas. Arctic 44(Supplement):164-171.

Tejedor, A., R. Sagarminaga, A. Canadas, R. De Stepanis and J. Pantoja. 2007. Modifications of maritime traffic off southern Spain. Int. Whal. Comm. Scientific Committee SC/59/BC7.

Tyack, P., J. Gordon and D. Thompson. 2003/2004. Controlled exposure experiments to determine the effects of noise on large marine mammals. Mar. Technol. Soc. J. 37(4):41-53.

Van Waerebeek, K., A.N. Baker, F. Felix, M. Iniguez, G.P. Sanino, E. Seechi, G. Slocum, D. Sutaria, A. van Helden, and Y. Wang. 2006. Vessel collisions with small cetaceans worldwide and with large whales in the Southern Hemisphere: building a standardized database. $58^{\text {th }}$ Annual
International Whaling Commission Meeting, May-June, 2006, St. Kitts, Paper SC/58/BC6.

Van Waerebeek, K. and R. Leaper. 2007. Report from the IWC Vessel Strike Data Standardization Group. Document SC/59/BC12.

Vanderlaan, Angela S.M. and C.T. Taggart. 2007. Vessel collisions with whales: the probability of lethal injury based on vessel speed. Marine Mammal Science 23(1):145-156.

Watkins, W.A., M.A. Daher, G.M. Reppucci, J.E. George, D.L. Martin, N.A DiMarzio an D.P. Gannon. 2000. Seasonality and distribution of whale calls in the North Pacific Oceanography 13(1:62-67).

Weirich, M.T. 2004. A review of worldwide collisions between whales and fast ferries. Int. Whal. Comm. Scientific Committee SC/56BC9.

Weinrich, M.T., R.D. Kenney and P.K. Hamilton. 2000. Right Whales (Eubalaena glacialis) on Jeffreys Ledge: a habitat of unrecognized importance? Marine Mammal Science 16(2):326-337.

Weinrich, M.T. and K. Pekarcik. 2007. The effectiveness of dedicated observers in reducing risks of marine mammal collision with ferries: a test of the technique. Int. Whal. Comm. Scientific Committee $\mathrm{SC} / 59 / \mathrm{BC} 11$.

Wiggins, S.M. 2003. Autonomous acoustic regording packages (ARPs) for long-term monitoring of whale sounds. Mar. Technol. Soc. J. 37:13-22.

Wiggins, S.M., M.A. McDonald, L.A. Munger, J.A. Hildebrand and S.E. Moore. 2004. Waveguide propagation allows range estimates for North Pacific Right Whales in the Bering Sea. Canadian Acoustics 32:67-78.

Wursig, B., J. Guerrero and G.K. Silber. Social and sexual behavior of Bowhead Whales in fall in the Western Arctic: a re-examination of seasonal trends. Mar. Mammal Sci. 9(1):103-110.

Yeomans, K. 2006. Speed limits proposed off East Coast to protect endangered whales. Professional Mariner Oct./Nov.,99:9,10.

Zerbini, A.N., P. Clapham, C. Berchok, A. Kennedy and B. Rone. 2009. Occurrence of the endangered North Pacific Right Whale (Eubalaena japonica) in the Bering Sea in 2008. Poster. Alaska Marine Science Symposium, Jan. 19-23, Anchorage, Ak. Online: http://doc.nprb.org/web/symposium/2009/2009 abstract book ALL.pdf

Zimmerman, M. and D. Potter. 2001. Active high frequency phased-array sonar for whale shipstrike avoidance. Oceans 2001 MTS/IEEE, Nov.5-8, Honolulu, Hi. 